\title{
Nursing workload in mental health
}

\author{
Sobrecarga de trabalho da Enfermagem em saúde mental
}

Sidnei Roberto Alves ${ }^{1}$, Reginaldo Passoni dos Santos ${ }^{1}$, Régio Marcio Toesca Gimenes ${ }^{2}$, Mirian Ueda Yamaguchi ${ }^{2}$

Objective: to compare the workload in nursing mental health professionals who work in the public service and the private service. Methods: this is a quantitative research conducted with 70 nursing professionals in two services. For data collection, the evaluation scale of the work impact on mental health services was applied. Results: in the overall analysis, there was no statistically significant difference in the average score for workload among professionals of both institutions. However, all subscale averages had statistical differences, and the subscale "emotional repercussions at work" showed the highest significance. Conclusion: the nursing staff from the private service had higher workload average.

Descriptors: Mental Health; Nursing; Working Conditions.

Objetivo: comparar a sobrecarga de trabalho entre profissionais de enfermagem em saúde mental que atuam em serviço público e aqueles do serviço privado. Métodos: pesquisa quantitativa, realizada com 70 profissionais de enfermagem em dois serviços. Para coleta de dados, aplicou-se a escala de avaliação do impacto do trabalho em serviços de saúde mental. Resultados: na análise global, não se observou diferença estatística significativa na média de pontos para sobrecarga de trabalho entre os profissionais das duas instituições. Entretanto, todas as médias das subescalas apresentaram diferenças estatísticas, sendo que a subescala "repercussões emocionais no trabalho" apresentou maior significância. Conclusão: a equipe de enfermagem do serviço privado apresentou maiores médias de sobrecarga.

Descritores: Saúde Mental; Enfermagem; Condições de Trabalho.

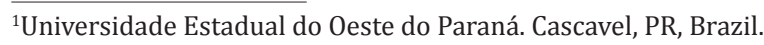

${ }^{2}$ Centro Universitário de Maringá. Maringá, PR, Brazil. 


\section{Introduction}

The mental health care services have undergone several changes, and the cause of these changes was the movement of the Psychiatric Reform, which promoted several changes in treatment to psychiatric patients in Brazil, being no longer centered on the biomedical model but in the individual's disease. Meanwhile, the practice of psychiatric nursing is also suffering innovations over the years ${ }^{(1)}$.

At the same time, there was the expansion of the Unified Health System, with the incorporation of integral concepts, health care, decentralization, regionalization and democratization to the daily life of health services ${ }^{(2)}$. However, the overwork in mental health services affects health and the welfare of workers, as well as the quality of care provided to patients. Thus, personal wear in the labor exercise of health professionals in psychiatric services has been the focus of recent research ${ }^{(3-4)}$.

Nevertheless, it is appropriate to note that diseases related to professional activity are a source of suffering and losses in the labor market. According to the International Labor Organization, 2.3 million deaths occur annually worldwide, and they have some connection with the activity of the worker. According to the report Prevention of occupational illnesses, about 2 million deaths in the world are a result of the development of professional illnesses and 321,000 are the result of accidents - about one death per accident for every six deaths by disease ${ }^{(5)}$.

Moreover, the new model of mental health care and its application are directly related to the skills and commitment of its employees. Thus, the indicator used to check overloading of workers could help to assess the mental health services, but also to promote proposals for the implementation to improve the quality of working life ${ }^{(6)}$.

Following this, it is important to stress that in a survey of the nursing staff in mental health public service, work overload favored the psychic and physical wear of professionals. Such wear is directly reflected in the professional job satisfaction ${ }^{(7)}$. Therefore, the aim of this study was to compare the workload among nursing mental health professionals who work in public service and the private service.

\section{Methods}

Research with descriptive-analytic design carried out in two psychiatric services (one public and one private) located in the southern Brazil.

Both services (public and private) are located in the same municipality of the northern Paraná, Brazil. In the public service, called Municipal Hospital of Maringá, there are 90 beds, 26 intended for mental service and having 22 nursing professionals. In this service, there are patients of the Unified Health System assisted, classified as low complexity and it began operations in 2003. The private psychiatric service, called at the Psychiatric Hospital of Maringá, had 240 beds for 61 nursing members. It was founded in 1962, with about 20 beds, being rapidly expanded due to the great demand of patients and families in the region and the state that was repressed.

The study included all members of the nursing staff of both institutions, being in labor activity in their respective institutions at the time of data collection. Thus, subjects in medical, leave, vacation certificate or who refused to participate in the study were excluded. From this, the sample of this research was 70 participants. The data were collected regarding age, marital status, gender, bonding time with the institution, number of employments, the level of education, professional training to characterize the study population.

The Impact Evaluation for Mental Health Work Services was used to assess the workload, which refers to a range built by the mental health division of the World Health Organization and subsequently validated 
in Brazil, already used in other similar studies ${ }^{(8-9)}$. This scale is self-administered and quantitative containing 18 items and three open questions. In this study, the results obtained from the answers to the quantitative items were shown, which address the perception of professionals about work overload and the gradual responses of Likert-type with five points were present: 1 - "in any way" ; 2 - "not much"; 3 - "more or less"; 4 - "very much" and 5 - "extremely". From the answers given by the professionals in the 18 quantitative items, they were grouped into three factors (subscales): effects on physical and mental health (whose internal consistency during the validation process was high and submitted alpha value $(\alpha)$ equal to 0.78 ); the effects on the functioning of the team (value of $\alpha=0.77$ ); emotional impact of the work (with $\alpha=0.70$ ).

Data collection took place between April and May 2013, with a table in Excel spreadsheet. The variables for the profile of the participants had an analysis on the distribution of absolute and relative frequencies. Comparative analysis of the workload among the participants took the average of points obtained in the quantitative items of the Labor Impact Scale Evaluation in Mental Health Services. In this sense, the normality assumptions were checked by Shapiro-Wilk test, and homogeneity by $\mathrm{F}$ test (analysis of variance). Thus, considering that the normal assumptions about homogeneity were accepted, the average of the variables was compared by applying the t-test for paired samples. Descriptive and inferential analysis were performed using the "R" software ${ }^{(10)}$, giving the differences statistically significant presenting p-value $<0.05$.

The study complied with the formal requirements contained in the national and international regulatory standards for research involving human beings.

\section{Results}

There were 21 of the 70 participants (30.0\%) belonging to the Municipal Hospital of Maringá and 49 (70.0\%) to the Psychiatric Hospital of Maringá. When comparing the profile of the professionals, it was found that regardless of the institution, women, with an average age above 30 years old, constituted the majority and who played mid-level/nursing technician activities (Table 1).

Table 1 - Profile of nursing professionals according to the psychiatric institution they worked

\begin{tabular}{|c|c|c|}
\hline \multirow[t]{2}{*}{ Variables } & $\begin{array}{c}\text { Municipal } \\
\text { Hospital of } \\
\text { Maringá( }(n=21)\end{array}$ & $\begin{array}{c}\text { Psychiatric } \\
\text { Hospital of } \\
\text { Maringá }(n=49)\end{array}$ \\
\hline & n(\%) & n(\%) \\
\hline \multicolumn{3}{|l|}{ Gender } \\
\hline Female & $17(80.9)$ & $33(67.3)$ \\
\hline Male & $4(19.1)$ & $16(32.6)$ \\
\hline Age (average) & 40.4 & 37.1 \\
\hline \multicolumn{3}{|l|}{ Education level } \\
\hline Mid-level/technical level & $11(52.0)$ & $39(80.0)$ \\
\hline Graduation & $2(10.0)$ & $5(10.0)$ \\
\hline Post-Graduation & $8(38.0)$ & $5(10.0)$ \\
\hline \multicolumn{3}{|l|}{ Graduation } \\
\hline Nursing Technician & $6(28.5)$ & $36(73.5)$ \\
\hline Nurse & $4(19.2)$ & $4(8.2)$ \\
\hline Operating nurse & - & $3(6.1)$ \\
\hline Average time of service (years) & 6.67 & 5.47 \\
\hline \multicolumn{3}{|l|}{ Another work link } \\
\hline Yes & $8(38.1)$ & $21(43.9)$ \\
\hline No & $13(61.9)$ & $28(57.1)$ \\
\hline
\end{tabular}


In the comparative analysis, there was no significant statistical difference between the professionals of both institutions, concerning the global burden $(\mathrm{p}=0.110)$. However, the comparison in each subscale points out that the three factors assessed in the private hospital nursing staff presented significantly greater average scores (Table 2).

Table 2 - Mental average score (standard deviation) of the factors related to the workload of professionals according to the mental health service.

\begin{tabular}{lccc}
\hline Scale & $\begin{array}{c}\text { Municipal } \\
\text { Hospital of } \\
\text { Maringá }\end{array}$ & $\begin{array}{c}\text { Psychiatric } \\
\text { Hospital of } \\
\text { Maringá }\end{array}$ & $\mathbf{p}^{*}$ \\
\hline Global overload & $1.48(0.15)$ & $1.72(0.17)$ & 0.110 \\
$\begin{array}{l}\text { Subscale1 } \\
\text { Effects of the team in the physi- } \\
\text { cal and mental health }\end{array}$ & $1.30(0.17)$ & $1.43(0.25)$ & 0.029 \\
$\begin{array}{l}\text { Subscale2 } \\
\text { Impact on the team working }\end{array}$ & $1.57(0.33)$ & $1.81(0.57)$ & 0.026 \\
$\begin{array}{l}\text { Subscale3 } \\
\text { Emotional impact of working }\end{array}$ & $1.58(0.37)$ & $1.93(0.52)$ & 0.036 \\
\hline T-test for paired sample & & &
\end{tabular}

\section{Discussion}

The limitation of this study is linked to the expansion of a multidisciplinary team of mental health and with the highest number of participants. Moreover, the development of research in only two psychiatric services prevented the largest selection of the sample. Another factor regarding this instrument was used to measure the workload of the nursing staff working in psychiatric services, restricting the analysis of the results. Further studies are needed to make more effective this assessment, with questions related to factors related to other situations, such as the causes of absenteeism at work, sickness, among others.

The results of this study can contribute to the critical analysis of the conditions and the nursing work process in mental health services, where the professionals may be predisposed to the levels of work overload.

There was a predominance of female participation among nursing human resources of both institutions. The inclusion of women in the formal labor market has been significant in many areas of the labor sector, due to increased education and the achievement of economic autonomy, among others. The health professions have absorbed part of the contingent of this working class $^{(11)}$.

In this same perspective, the profile of nursing professionals in mental health observed in this study is consistent with the profile of the working class as a whole. Recent study data conducted by the Federal Nursing Council in partnership with Oswaldo Cruz Foundation (Fiocruz) showed that the Brazilian nursing is predominantly female ${ }^{(12)}$.

Also on the profile of the participants, there is the need to have other employment showed higher among workers of a private institution. This fact leads to inferring that there is the low rate of payment among the factors associated with this feature. In addition to receiving lower salaries, the private health care worker often has no career plan and other benefits offered by the public sector, which motivates them to seek other work to supplement the family income ${ }^{(13)}$.

Comparing the workload, there was no significant difference in the evaluation of the overall overload between the groups. However, the nursing staff of private mental health service showed averages higher overloads in all aspects when considering the individual assessment of each subscale.

In this sense, the results showed that in the subscale1 (effects of the team in the physical and mental health) participants from both the public and the private service had the lowest average scores points $(1.30 \pm 0.17$ and $1.43 \pm 0.25$, respectively). Nevertheless, the literature indicates that the work of 
the professional with the mental patients can cause interference with physical complaints and workrelated stress in mental health. Thus, it is necessary that the nurse managers are attentive to the signs and symptoms presented by the team that often cannot verbally report such events, but manifest them in the form of absenteeism ${ }^{(3)}$. However, this is different from a study conducted in two pediatric hospitals in the United States that show the factors that generate work overloads, such as stress at work, burnout, emotional exhaustion, job dissatisfaction and burnout by work overload of these professionals ${ }^{(14)}$.

The subscale on the impact of overload on the operation of the team showed the most significant difference between the teams $(\mathrm{p}=0.026)$. On this, there is the professional's fear regarding the possibility of being attacked, the general state of physical health and sick leave as factors associated with overload and they can cause stress to the entire team and disagreements between its members, affecting labor structure and dynamics of the service as a whole $\mathrm{e}^{(15)}$.

It was found that in private service, professionals have a lower average time (in years) of service, and more employments. This may explain the high in the statistical difference observed in subscale2 since there can be no close relationship of proximity between the couple among these professionals. This closeness between the staff in the workplace promotes unity and cooperation of the members and therefore confirms that there may be a joint elaboration of strategies for coping with difficulties arising from overload $^{(4)}$.

When analyzing the results, although the aspects related to "emotional repercussions of work" (subscale3), had the highest average overload among workers of both institutions $(1.58 \pm 0.37$ for the professionals in the public service and $1.93 \pm 0.52$ for the private service staff).

Therefore, it is noted that inadequate conditions of work and reduced autonomy, combined with physical overload and lack of labor cooperation between team members, are factors that affect the psyche of professionals in mental health services and often, they are reasons for suffering and emotional lability among workers of this area $\mathrm{a}^{(1,3-4,15)}$. On the other hand, the workload directly influences the assistance, undermining the quality of service, compromising the safety of the patient. In the same direction, it is emphasized that working conditions have repercussions on the quality of working life on the nursing team ${ }^{(16)}$.

It is necessary to be aware of the fact that all these aspects related to work wear of the nursing team are reflected in job satisfaction with the service in which they operate and in health care quality dispensed to patients. Thus, it is very important and emerging to conduct a situational, strategic planning in the context of psychiatric institutions to identify possibilities, minimizing the excessive workload that the professionals are exposed ${ }^{(7)}$. In another study conducted with 400 nurses in Iran, it was described that the workload is influenced by several factors, including environmental conditions, structural work $\operatorname{process}^{(17)}$.

In this regard, improvements in the labor process, the increase in the number of human resources in nursing and greater appreciation of them, music education in the workplace, team training for the implementation of an interdisciplinary approach activities and multidisciplinary cooperation, aiming at comprehensive care are some of the strategies listed in the literature ${ }^{(3-4,6-7,18)}$.

Therefore, it is expected that this research will provide discussions and actions to reduce the workload for professionals working in mental health services, and new studies are suggested that allow comparison with results found in this investigation of the studied topic. 


\section{Conclusion}

The nursing professionals of service they worked showed similar characteristics of their profile, and similar to the Brazilian nursing profile.

About the workload in the overall evaluation, there were no statistical differences in the average overload between the groups. However, the nursing staff in the private service had higher overload average in the analysis of each subscale.

\section{Collaborations}

Alves SR and Yamaguchi MU contributed to the design, data collection, analysis, data interpretation and writing of the article. Santos RP and Gimenes RMT contributed to the design and final approval of the version to be published.

\section{References}

1. Braga FS, Olschowsky A. Pleasure and suffering in the work of mental health nurses in the context of the psychiatric reform. Rev Enferm UFPE online [Internet]. 2015 [cited 2016 Apr 26];9(3):708694. Available from: http://www.revista.ufpe.br/ revistaenfermagem/index.php/revista/article/ view/6295/pdf_7391

2. Azevedo DM. Evaluation of health services: current perspectives of mental health research [editorial]. Rev Enferm UFPE online [Internet]. 2011 [cited 2013 Oct 15];5(8). Available from: http://www. revista.ufpe.br/revistaenfermagem/index.php/ revista/article/view/2162/pdf_673

3. Souza SRC, Oliveira EB, Mauro MYC, Mello R, Kestemberg CCF, Paula GS. Cargas de trabalho de enfermagem em unidade de internação psiquiátrica e a saúde do trabalhador. Rev Enferm UERJ. 2015; 23(5):633-8.

4. Avelino DC, Silva PMC, Costa LFP, Azevedo EB, Saraiva AM, Filha MOF. Trabalho de enfermagem no centro de atenção psicossocial: estresse e estratégias de coping. Rev Enferm UFSM. 2014; 4(4):718-26.
5. Organização Internacional do Trabalho. A prevenção das doenças profissionais [Internet]. 2013 [citado 2013 out 10]. Disponível em: http://www. ilo.org/public/portugue/region/eurpro/lisbon/ pdf/safeday2013_relatorio.pdf

6. Camilo CA, Bandeira M, Leal RMAC, Scalon JD. Avaliação da satisfação e sobrecarga em um serviço de saúde mental. Cad Saúde Coletiva. 2012; 20(1):82-92.

7. Souza IAS, Pereira MO, Oliveira MAF, Pinho PH, Gonçalves RMDA. Work process and its impact on mental health nursing professionals. Acta Paul Enferm. 2015; 28(5):447-53.

8. Leal RMAC, Bandeira MB, Azevedo KRN. Avaliação da qualidade de um serviço de saúde mental na perspectiva do trabalhador: satisfação, sobrecarga e condições de trabalho dos profissionais. Psicol Teor Prat. 2012; 14(1):15-25.

9. Alves AP, Guidetti GECB, Diniz MA, Ferreira LA, Zuffi FB. Avaliação do impacto do trabalho em profissionais de saúde mental de uma instituição psiquiátrica. Rev Min Enferm. 2013; 17(2):424-8.

10. R Development Core Team. R: a language and environment for statistical computing. Vienna: $\mathrm{R}$ Foundation for Statistical Computing [Internet]. 2013 [cited 2016 Mar 13]. Available from https:// cran.r-project.org/doc/manuals/r-release/ fullrefman.pdf

11. Nunes EFPA, Santini SML, Carvalho BG, Junior LC. Força de trabalho em saúde na atenção básica em municípios de pequeno porte do Paraná. Saúde Debate. 2015; 39(104):29-41.

12. Conselho Regional deEnfermagemdo Paraná. Perfil da enfermagem no Brasil: principais informações [Internet]. 2015 [citado 2015 nov 27]. Disponível em: http://www.corenpr.gov.br/portal/images/ lai/RelatorioConcisoPerfilEnfermagem.pdf

13. Barbosa ALNH, Barbosa Filho FH. Diferencial de salários entre setores público e privado no Brasil: um modelo de escola endógena. [Internet]. 2012 [citado 1016 Mar 13]. Disponível em: http:// www.ipea.gov.br/portal/images/stories/PDFs/ TDs/td_1713.pdf 
14. Holden RJ, Scanlon MC, Patel NR, Kaushal R, Escoto $\mathrm{KH}$, Brown R L, et al. A human factors framework and study of the effect of nursing workload on patient safety and employee quality of working life. BMJ Qual Saf. 2011; 20(1):15-24.

15. Schmoeller R, Trindade LL, Neis MB, Gelbcke FL, Pires DEP. Cargas de trabalho e condições de trabalho da enfermagem: revisão integrativa. Rev Gaúcha Enferm. 2011; 32(2):368-77.

16. Mohammadi M, Mazloumi A, Kazemi1 Z, Zeraati H. Evaluation of Mental Workload among ICU Ward's Nurses. Health Promot Perspect. 2015; 5(4):2807.
17. Bahadori M, Ravangard R, Raadabadi M, Mosavi SM, Fesharaki GM, Mehrabian F. Factors affecting intensive care units nursing workload. Iran Red Crescent Med J [Internet]. 2014 [cited 2016 Mar 13]; 16(8):e20072. Available from: http://www. ncbi.nlm.nih.gov/pmc/articles/PMC4222019/

18. Oliveira FB, Silva JCC, Silva VHF, Cartaxo CKA. O trabalho de enfermagem em saúde mental na estratégia de saúde da família. Rev Rene. 2011; 12(2):229-37. 